\title{
HOLOEXPO 2020: краткие итоги
}

\author{
В Москве 8-9 сентября 2020 года прошла XVII Международная конференция \\ по голографии и прикладным оптическим технологиям. Актуальность \\ мероприятия связана с большим вниманием к направлению микро-нано-фотоники \\ и оптоэлектроники России и за рубежом. Голографические технологии и методы, \\ будучи внедренными в самые различные технические области, придают им \\ необыкновенные качества и повышают их эффективность.
}

\section{$\Pi$} римером этого может служить развитие защитной голографии с получением цветных 3D-изображений на основе мультиспектральных фотополимерных материалов, применение голограммных и дифракционных оптических элементов (ГОЭ-ДОЭ) в 3D-дисплеях, устройствах визуального наблюдения (дополненной реальности, прицелах). Активно развивается цифровая голография и компьютерные методы синтеза голограмм, их применение для систем отображения 2D/3D-изображений, для датчиков волнового фронта, в устройствах оптико-голографической памяти, голографических корреляторах распознания изображений. В связи с созданием новых многоцветных лазеров и высококачественных фотоматериалов активно развивается изобразительная голография, а также некоторые другие применения голографии в прикладных оптических технологиях.

Несмотря на распространение новой коронавирусной инфекции COVID-19, проведение ежегодных Международных конференций HOLOEXPO остается очень важным и актуальным научнотехническим мероприятием. Доклады участников и выставочная продукция позволяют оценить состояние рынка голографических технологий и изделий, новейших научно-технических разработок в области голографии и определить ее основные направления развития в этой непростой эпидемиологической ситуации в Мире.

XVII Международная Конференция HOLOEXPO 2020 по голографии и прикладным оптическим технологиям прошла 8-9 сентября 2020 года в отеле «Золотое Кольцо» (Москва, Россия) и собрала с учетом докладчиков, аспирантов и студентов 87 человек.

Организаторами XVII Международной конференции HOLOEXPO 2020 выступили: Московский государственный технический университет им. Н. Э. Баумана (МГТУ им. Н. Э. Баумана, Москва, Россия), АО «НПО «КРИПТЕН" (Дубна, Россия),
ЗАО "ГОЛОГРАФИЧЕСКАЯ ИНДУСТРИЯ» (МИНСК, Республика Беларусь), ОоО "ХолоГрэйт" (СанктПетербург, Россия), АО "НТЦ "Атлас» (Москва, Россия), АО «НПО Государственный институт прикладной оптики" (Казань, Россия), ООО "Джеймс Ривер Бранч» (Москва, Россия), ООО "Альянс оптических систем" (Москва, Россия), АО "Красногорский завод им. С.А. Зверева" (Красногорск, Россия), ООО “Оптико-голографические приборы" (Москва, Россия)

Генеральным спонсором конференции выступило АО "Научно-производственное объединение "КРИПТЕН" (г. Дубна, Россия).

Спонсорами конференции стали:

- ЗАО «ГОЛОГРАФИЧЕСКАЯ ИНДУСТРИЯ", Минск, Беларусь;

- ООО "ХолоГрэйт", Санкт-Петербург, Россия;

- АО "Научно-технический центр "Атлас", Москва, Россия;

- ООО “Джеймс Ривер Бранч", Москва, Россия;

- ООО "Оптико-голографические приборы", Москва, Россия;

- ООО "Альянс оптических систем", Москва, Россия;

- АО «НПО «Государственный институт прикладной оптики", Казань, Россия;

- Общественная Научно-техническая Академия "КОНТЕНАНТ", Красногорск, Россия.

Организационные функции в дни проведения конференции приняла на себя компания ООО “Оптико-голографические приборы" (Москва, Россия).

Информационную и рекламную поддержку оказали российские научно-технические журналы "Мир техники кино" (Москва), "ФОТОНИКА", издательства "ТЕХНОСФЕРА" (Москва), "КОНТЕНАНТ" (г. Красногорск, Московской области).

Открыла конференцию церемония вручения наград одного из старейших научно-технических обществ России - Оптического общества им.Д.С. Рождественского. Директор общества 
Арпишкин Владимир Михайлович (Санкт-Петербург, Россия) в соответствии с совместным решением президиума Оптического общества им. Д.С. Рождественского и Программного комитета международной конференции HOLOEXPO 2020 вручил памятные знаки общества:

Медалью

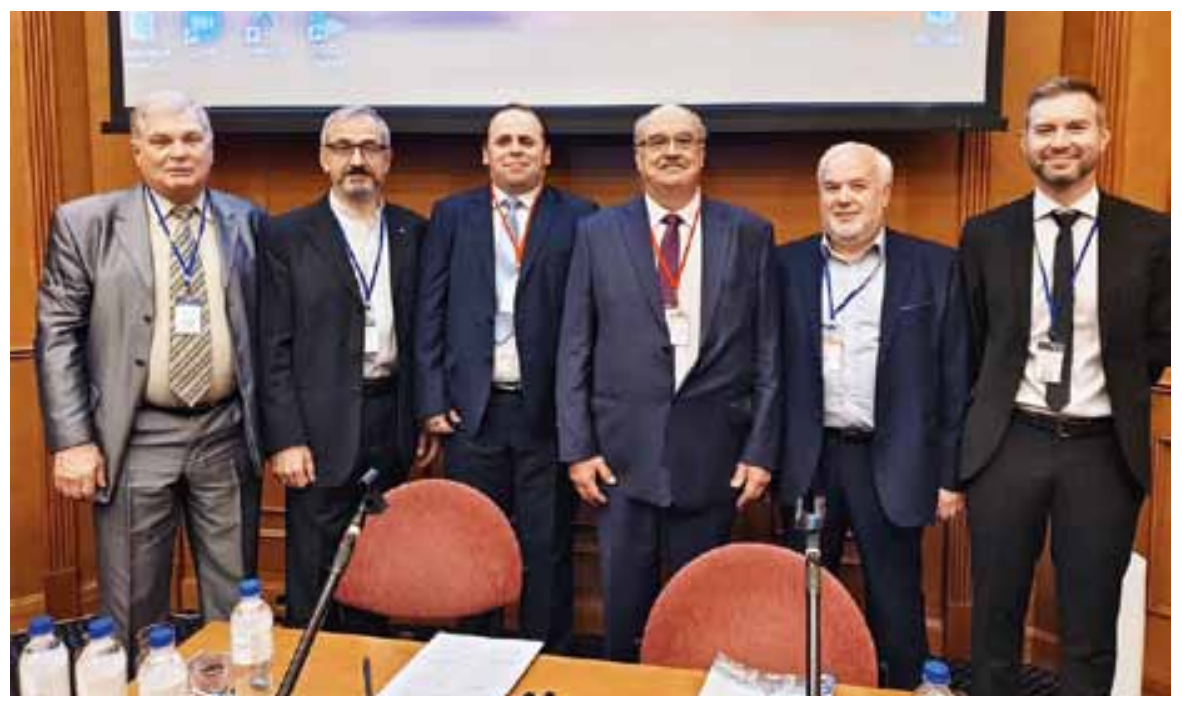

С.И. Вавилова был награжден Евтихиев Николай Николаевич, д. Ф.--м.н., профессор, Генеральный директор ООО НТО "ИРЭ-Полюс", Заслуженный деятель науки РФ, Лауреат Государственной премии в области науки 2004 года.

Медалью имени Д.С. Рождественского были награждены: Павлычева Надежда Константиновна, д.т.н., профессор, Казанский национальный исследовательский технический университет им. А.Н. Туполева КНИТУ- КАИ; Одиноков Сергей Борисович, Председатель Организационного комитета HOLOEXPO 2020, доктор технических наук, профессор, заместитель директора НИИ РЛ МГТУ им. Н. Э. Баумана

Медалью имени Ю.Н.Денисюка были награждены: Кайтуков Чермен Борисович, ведущий специалист, АО "Научно-технический центр "Атлас"; Танина Людмила Николаевна, Генеральный директор ООО "Магия света"; Смирнов Леонид Игоревич, нач. отдела АО "НПО “КРИПТЕН"; Вишняков Геннадий Николаевич, д.т.н, профессор, нач. лаборатории ФГУП ВНИиОФИ; Злоказов Евгений Юрьевич, к.ф-м.н., доцент кафедры «Лазерная физика", НИяу "МИФИ".

Конференция проводилась в соответствии с программой конференции. В ней участвовали представители таких организаций, как ООО "ХолоГрэйт» (Санкт-Петербург, Россия), АО «НТЦ "Атлас» (Москва, Россия), АО “НПО «КРИПТЕН" (г. Дубна, Россия), ООО "Джеймс Ривер Бранч» (г. Москва, Россия), ООО "Альянс оптических систем" (г. Москва, Россия), АО "НПО "ГИПО" (Казань, Россия), КНИТУ-КАИ (Казань, Россия), АО “Гознак" (Москва, Россия), ООО "Компания "Азимут Фотоникс" (Москва, Россия), ООО "ФАРЭКСПОРТ" (Санкт-Петербург, Россия), ООО НТО «ИРЭ-Полюс» (г. Фрязино, Моск. обл., Россия), АО «Фазотрон3ОМЗ-АВИА" (г. Сергиев-Посад, Моск. обл., Россия), ООО “Исследовательский центр Самсунг» (Москва, Россия), Научно-исследовательский институт

АО "Гознак" (Москва, Россия), ВНИИ оптико-физических измерений (Москва, Россия), Институт автоматики и электрометрии СО РАН (Новосибирск, Россия), Институт систем обработки изображений (г. Самара, Россия), МГТУ им. Н. Э. Баумана (Москва, Россия), НИЯУ "МИФИ" (Москва, Россия), Университет ИТМО (Санкт-Петербург, Россия), Физический институт им. П.Н. Лебедева РАН (Москва, Россия).

Открыл пленарное заседание доклад д.т.н., профессора С. Б. Одинокова "Современные голографические технологии: тенденции развития и применение в прикладной оптике» (МГТУ имени Н.Э. Баумана, Москва, Россия). В сообщении был приведен анализ современных направлений, в которых развивается голография. Отмечалось, что наиболее прорывные технологии появились в области цифровой голографии и компьютерной голографии. Цифровая голография (ЦГ) позволяет непосредственно регистрировать голограммы с помощью матричных приемников излучения (без использования традиционных фотопластинок и материалов) и выполнять обработку и восстановление голографических изображений в цифровой форме в компьютере. Компьютерная голография (КГ) позволяет осуществлять синтез голограмм в компьютере, формировать математическую модель дифракционных и интерференционных оптических полей, выполнять все необходимые преобразования в компьютере, а затем визуализировать конечную компьютерно- синтезированную голограмму (КСГ) в оптическом виде (канале, схеме) с помощью пространственных модуляторов света. Рассмотрено применение новых методов ЦГ и КГ в следующих направлениях: а) для получения защитных голограмм с новыми визуальными 
эффектами на основе плазмонных дифракционных решеток в рельефно-фазовых тонкопленочных фотоматериалах; б) для создания голограммных и дифракционных оптических элементов в очках дополненнной реальности и в оптических системах и объективах видимого и ик-диапазона; в) в датчиках волнового фронта и в оптикоголографической архивной памяти, в том числе с записью мультиплексных микроголограмм Фурье фотопроекционным методом. Также рассмотрены конкретные примеры использования методов и схемотехники ЦГ и КГ в голографической микроскопии и интерферометрии, в терагерцовой голографии, в голографических корреляторах при обработке изображений, в изобразительной голографии и в других применениях.

В режиме онлайн участник конференции из Казани д.т.н., профессор, А.В.Лукин, АО "НПО "ГИПО" в докладе "Объединенные метрологические возможности осевых синтезированных голограмм и эталонных пробных стекол для поверки и калибровки средств измерений" рассмотрел потенциал метрологических возможностей совместного применения осевых синтезирован ных голограмм и эталонных пробных стекол. Их использование в качестве элементов эталонного набора позволит решить задачи поверки и калибровки контактных и бесконтактных средств измерений, обеспечивающих технологический и аттестационный контроль процессов формообразования оптических поверхностей. Были приведены результаты натурного моделирования.
Доклад д.т.н., профессора Г.И. Грейсуха "Дифракционные микроструктуры: перспективы развития и ограничения" (ПГУАС, г. Пенза, Россия) отразил новый взгляд на методы исследования многослойных дифракционных микроструктур, основанные на совместном использовании Q-факторов, полученных в бесконечно тонком приближении в рамках скалярной теории дифракции, и метода строгого анализа связанных волн. Такой подход позволяет достоверно оценить предельные спектральные и угловые характеристики многослойных микроструктур различных типов. Опираясь на эти оценки, проанализированы пути и перспективы совершенствования микроструктур.

В докладе д.т.н., профессора С.Б. Одинокова «Разработка ГОСТа Голография-2020. Термины и определения. Цифровая и компьютерная голография. Методы измерения Дифракционной эффективности", (МГТУ имени Н.Э.Баумана, Москва, Россия) был представлен вариант проекта нового ГОСТа. В нем термины, понятия и методы приведены в современной интерпретации. Включены понятия как аналоговой голографии, реализуемой с помощью физически существующих оптических полей, так цифровой и компьютерной голографии, реализуемых с помощью математически задаваемых волновых полей оптического диапазона длин волн и ТГЦ-диапазона длин волн. Приведены понятия дифракционной эффективности, угловой и спектральной селективности голограмм, схемы измерения дифракционной эффективности разного типа голограмм

С. Г. Каленков, д.ф.- М.н., профессор Московского политехнического университета, выступил с докладом "Регистрация гиперспектральных и объемных цифровых голограмм". Им были рассмотрены принципы и техника регистрации и реконструкции цифровых гиперспектральных голограмм. Оптическая схема регистрации содержит сканирующий интерферометр и источник полихроматического излучения. Докладчик показал глубокую аналогию между объемными (толстослойными) голограммами Денисюка и цифровыми голограммами, которые регистрируются для каждого положения сканирующего зеркала. Именно: каждую 
цифровую голограмму, записан ${ }^{-}$ ную при некотором определенном смещении зеркала, можно уподобить соответствующему ей зеркальному фотослою в толстой голограмме Денисюка. Приведены результаты исследований влияния шумов различной природы на качество восстановления цифровых голографических изображений.

Конкретным применениям адресных волоконных брэгговских структур было посвящено выступление А.А. Кузнецова (Казанский национальный исследовательский технический университет имени А.Н. Туполева - КАИ, Казань, Россия). Он представил определенные требо-

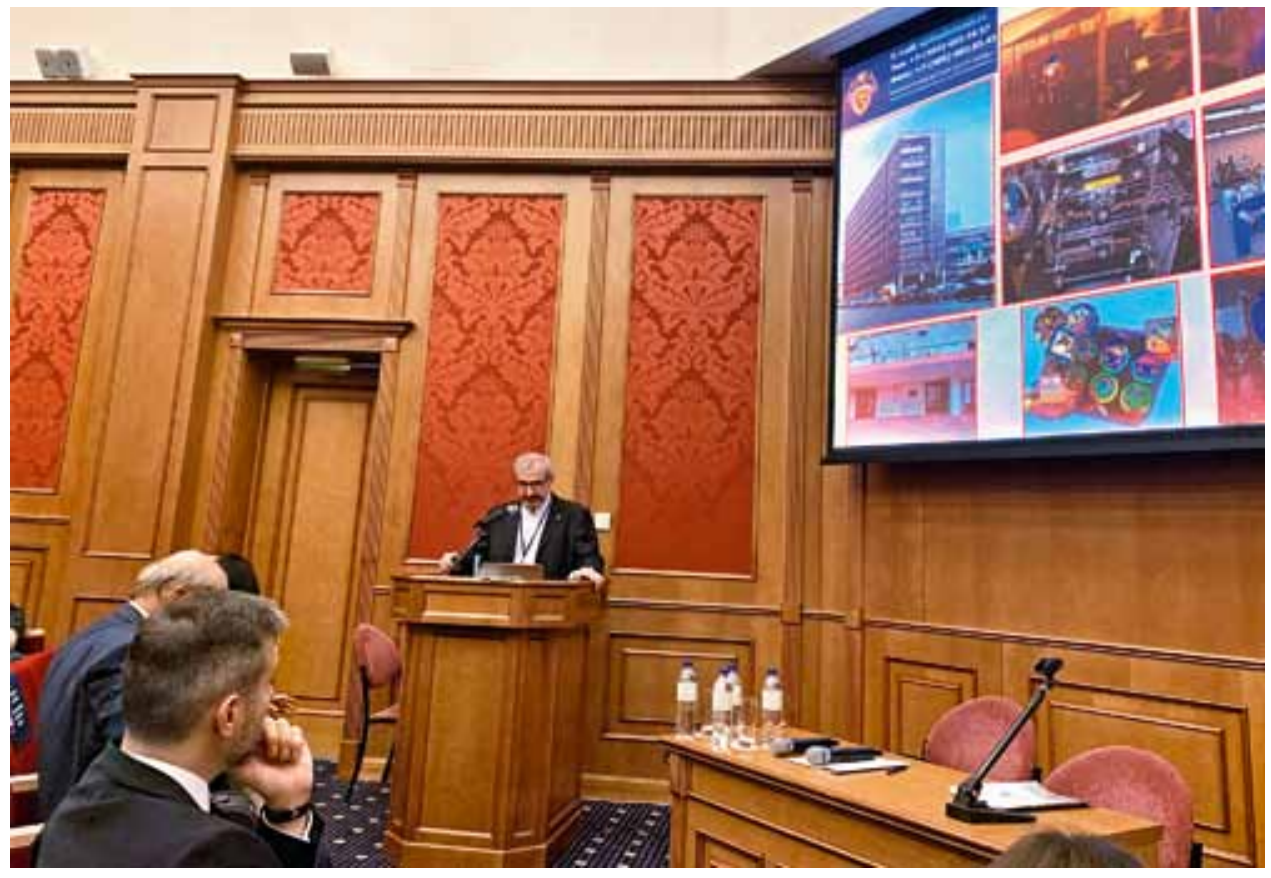
вания на форму спектра отражения / пропускания структур, которые определяются профилем показателя преломления входящих в их структуру брэгговских решеток. Общими требованиями к указанным структурам являются ширина полосы пропускания отражающих/пропускающих адресных элементов в 0,5-1 пм и частотный разнос между ними в 10-40 ГГц, обеспечивающие высокую разрешающую способность измерений различных физических величин. В работе были рассмотрены голографические методы записи на основе фазовых масок, интерферометров Тальбота и Ллойда и их комбинаций для реализации симметричных и несимметричных адресных волоконных брэгговских структур, позволяющие выполнить указанные выше требования.

А.П.Погода (Балтийский государственный технический университет "ВОЕНМЕХ" имени Д.Ф. Устинова, Санкт-Петербург, Россия) предста-

вила доклад об отражательных решетках Брэгга, которые возникают за счет интерференции распространяющихся в резонаторе волн. Пространственная периодическая модуляция коэффициента усиления активной среды связана с соответствующей периодической модуляцией показателя преломления. В статье приводятся результаты экспериментальных исследований влияния решеток Брэгга на спектры генерации на примере импульсного $\mathrm{Nd}$ :YAG лазера. Показано, что при определенном выборе режима формирования отражательных решеток коэффициента усиления, ширина полосы генерации может быть уменьшена в 3-5 раз при соответствующем увеличении энергии в импульсе и заметном улучшении пространственного качества пучка.

Н.В.Никоноров, д.ф.- м.н., профессор Национального исследовательского университета ИТМО,

\section{Оптико-голографические приборы}

- проведение научно-исследовательских, опытно-контрукторских и опытно-технологических работ в области голографических технологий

- изготовление голограммных и дифракционных оптических элементов

- разработка и создание оптико-голографических устройств дополненной реальности (AR-технологии), устройств контроля подлинности защитных голограмм - организация и проведение тематических конференций, школ, семинаров и выставок в области голографических технологий
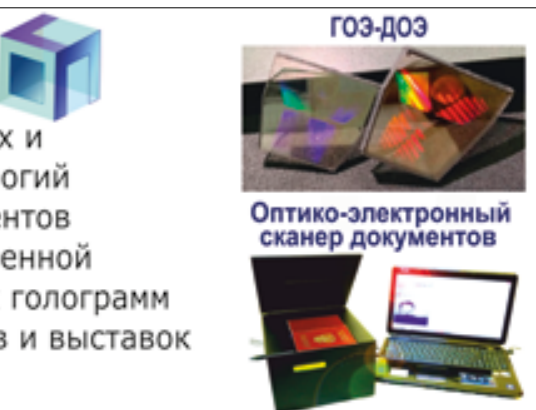

ООО «ОГП» РФ, 107076, г. Москва, ул. Матросская тишина, д. 23, стр. 2, под. 1а, эт. 5, п. XXV, к. 18, тел.: +7(499)263-63-44, e-mail: kus_a_s@mail.ru 


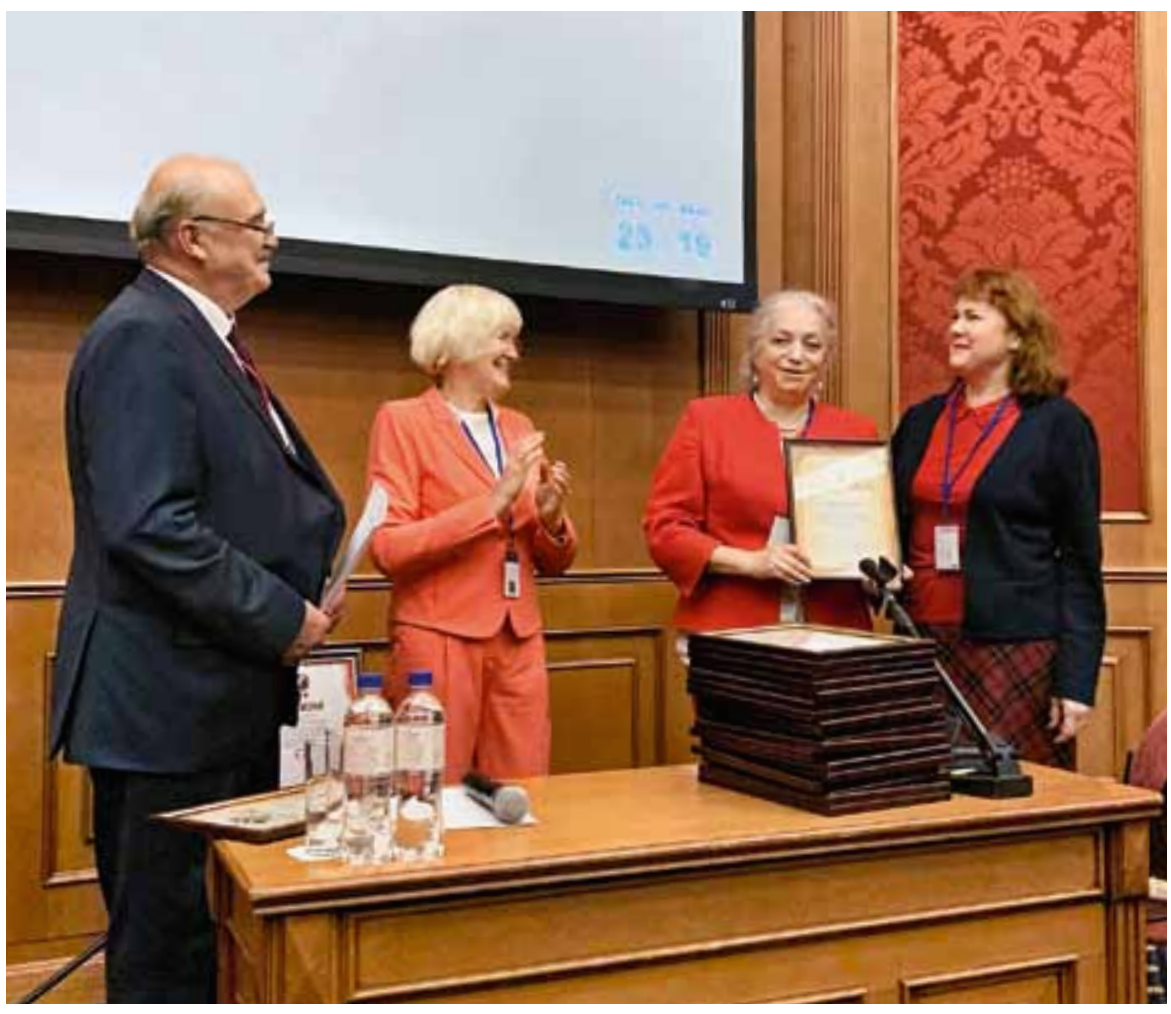

построенных на базе волноводных голограмм.

В докладе Р.В.Скиданова, д.ф.- М.н. (Институт систем обработки изображений филиал ФНИЦ "Кристаллография и фотоника" Российской академии наук, Самара, Россия) было показано, что возможно создание компактного изображающего объектива, который в пределе может быть реализован как почти плоская структура с нулевым рабочим отрезком. Методом прямой лазерной записи изготовлена кольцевая гармоническая отражающая линза, на основе которой собран предложенный объектив. Проведено экспериментальное исследование объектива в режиме построения изображений источников света и светотехнической миры для тестирования

Санкт-Петербург, Россия, представил обзорный материал по созданию и применению фото-терморефрактивных (ФТР) стекол в России и за рубежом. Выдал историческую справку по разработке таких материалов. Продемонстрировал многофункциональные свойства ФТР стекол. Показал примеры использования ФТР стекол в голографии, сенсорике, лазерной технике и т.д. Рассматривал перспективы создания на основе ФТР стекол элементной базы фотоники нового поколения с уникальными характеристиками.

А.П.Владимиров, д.т.н., профессора Уральского федерального университета, Екатеринбург, Россия, рассматривал аппаратуру и методику, использованные в исследованиях по динамической спекл-интерферометрии деградации авиационной техники и живых клеток. Проанализированы возможности практического применения полученных данных.

А.Н.Путилин, к.Ф.- М.н. (Физический Институт имени П.Н. Лебедева Российской академии наук, Москва, Россия) осветил основные свойства голографических волноводных перископических мультиплексоров выходного зрачка оптических систем дисплеев дополненной реальности. Привел анализ ограничений в работе волноводных голограмм, компенсации хроматизма в перископических схемах и влияние дефектов волноводов на работу дисплеев дополненной реальности объективов. Показано, что предложенная схема изображающего объектива на основе отражающей кольцевой гармонической линзы является работоспособной.

В.П.Корольков, д.т.н., профессор (Институт автоматики и электрометрии Сибирского отделения Российской академии наук, Новосибирск, Россия) рассмотрел перспективы развития прецизионных лазерных и плазменных технологий, которые подкреплены улучшением функциональности и снижением погрешностей аналитических приборов, которые создают новые возможности в области синтеза микро-наноструктурированных оптических компонентов и продуктов прецизионной микрообработки. Выполнение серии проектов ФЦП, РНФ и РФФИ позволило создать в ЦКП ИАиЭ СО РАН комплекс оборудования, позволяющего решать широкий ряд прикладных и фундаментальных задач. В докладе показаны возможности отдельных компонентов этого комплекса и примеры их применения. Уникальность и доступность созданного технологического комплекса будут полезны для реализации российских и международных проектов в области голографии, интегральной и волоконной оптики, сенсорики и микросистемной техники.

С. М. Шандаров, д.ф.- М.н., профессор (Томский государственный университет систем управления и радиоэлектроники, Томск, Россия) в докладе 
"Адаптивная голографическая интерферометрия в приложении к определению материальных параметров фоточувствительных кристаллов" рассмотрел применение методов голографической интерферометрии, основанных на взаимодействии стационарного опорного светового пучка с фазово-модулированным сигнальным пучком на создаваемых ими возмущениях диэлектрического тензора в фоточувствительных кристаллах, для измерения материальных параметров, определяющих величину этих возмущений. Определил экспериментальные условия, при которых возможно выделение вкладов во взаимодействие флексоэлектрического и электрогирационного эффектов в кубических фоторефрактивных кристаллах класса силленитов; показал необходимость учета вклада в него эффекта флексогирации.

Р.С. Стариков (Национальный исследовательский ядерный университет "МИФИ", Москва, Россия) сделал доклад "Микрозеркальный ПВМС как голографический носитель: новейшие возможности и применения" и посвятил рассмотрению современных возможностей применения микрозеркальных пространственно-временных модуляторов света в качестве средства ввода компьютерно синтезированных и цифровых голограмм. Рассматривал особенности модуляции света, осуществляемой микрозеркальными модуляторами, приводятся и обсуждаются примеры реализации голограмм различных типов с их помощью, а также голографических систем различного назначения на их основе.

С.А.Шойдин, к.ф.- М.н., доцент (Сибирский государственный университет геосистем и технологий, Новосибирск, Россия) в работе «Передача голографической информации супергетеродинированием" приводит способ сжатия 3D голографической информации без недопустимых потерь качества изображения. Показал, что он аналогичен известному в радиотехнике методу супергетеродинирования, или переносу информационных характеристик сигнала на более низкую несущую частоту и заключается в представлении 3D изображения двумя кадрами, один из которых представляет собой топографическую карту поверхности, а другой ее текстуру. Указанное представление удобно для динамической передачи 3D кадров по обычным каналам связи в задачах 3D голографического телевидения и дополненной реальности.

Все состоявшиеся 41 пленарных и секционных доклада были разбиты на тематические секции:

- 16 Пленарных докладов по наиболее важным темам в области голографии;
- Технологии в области защитных голограмм 4 доклада.

- Формирование изображений и отображение информации с помощью голограммной оптики - 4 докладов.

- Голограммные и дифракционные оптические элементы: методы компьютерного синтеза, метаматериалы, плазмонные структуры и технологии изготовления - $\mathbf{5}$ докладов.

- Объемная голография и фоточувствительные материалы для голографии - 6 докладов.

- Голографическая интерферометрия, голографическая память, оптико-голографическая обработка информации - 6 докладов.

Также было представлено на конференции было 12 стендовых докладов.

Общее число представленных на конференции докладов составило - 53 доклада.

На конференции была проведена демонстрация образцов оптомеханики, оптоэлектронных компонентов и лазерного оборудования, рекламной продукции представителей ООО "ХолоГрэйт" (Санкт-Петербург, Россия), ООО "ФАРЭКСПОРТ" (Санкт-Петербург, Россия), ООО "Компания "Азимут Фотоникс" (Москва, Россия), ООО "Альянс

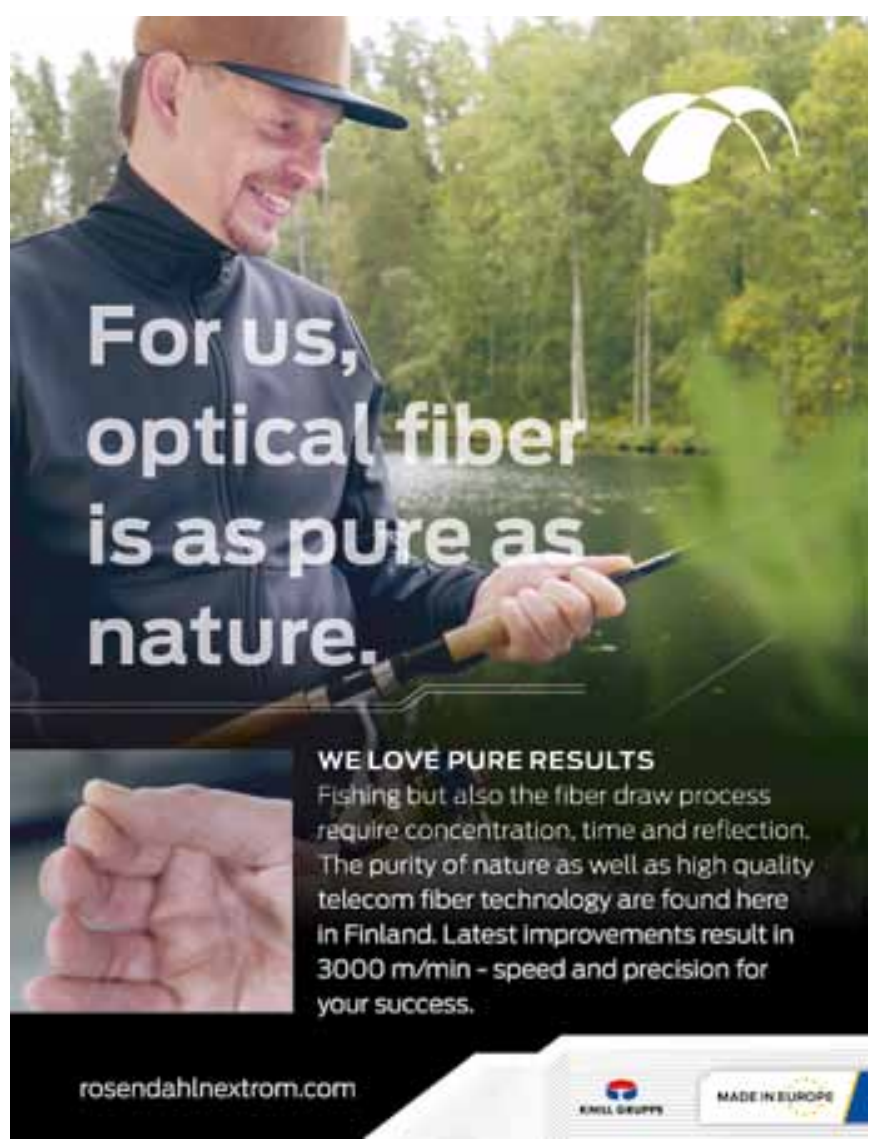


оптических систем" (Москва, Россия); распространялись номера научно-технических журналов "Мир техники кино" и "ФОТОНИКА".

По мнению организаторов, участников и гостей XVII Международной конференции HOLOEXPO 2020 конференция состоялась как событие, органично сочетающее в себе производственный потенциал, инженерные и научные идеи, предпринимательские интересы. По итогам прошедшей конференции участниками были сформулированы следующие наиболее актуальные направления в оптической голографии.

1. В области защитной голографии: разработка новых защитных признаков, в том числе связанных с формированием цветных голографических изображений с элементами движения и динамики; разработка поляризационных изображений, считываемых как обычными поляризаторами, так и в автоматическом режиме с помощью смартфонов; разработка устройств записи/считывания персонализированных кодированных скрытых изображений индивидуально для каждой голограммы из серии; комбинирование цветных 3D аналоговых изображений с цифровыми

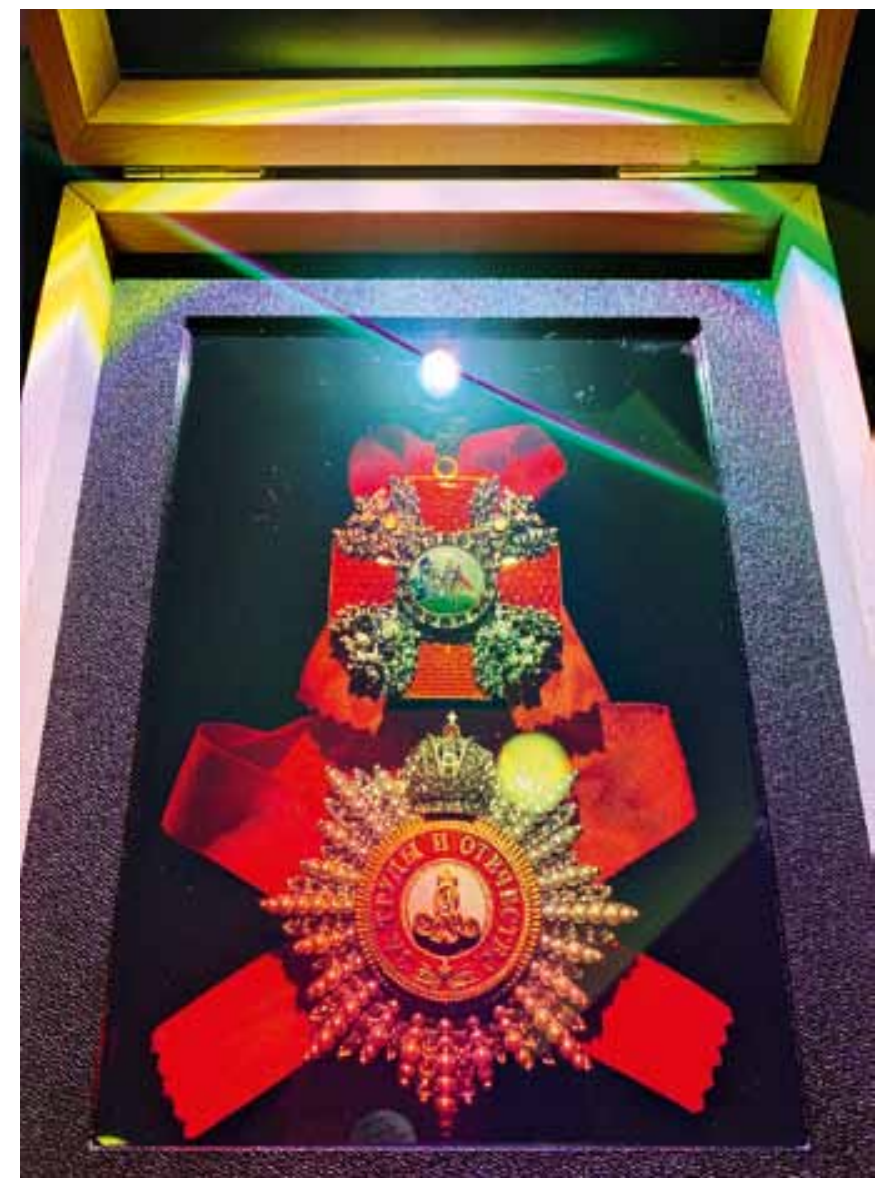

изображениями, получение плазмонных высокочастотных и низкочастотных дифракционных решеток с помощью новых систем дот-матрикс, а также внедрение в практику новых фоточувствительных материалов для защитной голографии (фотополимеры, тонкопленочные метаматериалы и др.).

2. В области создания дифракционных и голограммных оптических элементов (ГОЭ-ДОЭ) внедрение новых методов компьютерного синтеза голограмм Фурье-Френеля и современных методов компьютерного моделирования этих компонентов, а также применения для их изготовления новейших фоточувствительных сред в виде фото-терморефрактивных стекол, обладающих уникальными эксплуатационными параметрами.

3. В области голографической интерферометрии и микроскопии, датчиков волнового фронта, корреляционных систем распознавания изображений и голографической памяти - широкое внедрение методов цифровой голографии, цифрового синтеза голограмм и голографических фильтров с использованием современных мегапиксельных пространственных модуляторов света и мультипиксельных высокоскоростных фото-видео-камер, позволяющих создавать оптико-голографические устройства и когерентные и некогерентные системы без использования фотоматериалов и их физико-химической постобработки.

4. В области изобразительной голографии - широкое внедрение компьютерных методов синтеза цветных 3D цифровых голограмм, а также создание мобильных установок на основе многоцветных лазеров для записи цветных голограмм уникальных объектов истории и искусства по методу Ю.Н.Денисюка, представлены выставочные образцы изобразительных голограмм (Кузнецов В.П., Новосибирск, Россия).

На церемонии закрытия конференции 25 представителям научных коллективов были вручены почетные дипломы за активное участие и спонсорскую помощь, а также за высокие научные достижения, продемонстрированные во время проведения XVII Международной конференции HOLOEXPO 2020.

Председатель Оргкомитета XVII Международной конференции HOLOEXPO 2020, доктор технических наук, профессор С.Б. Одиноков 


\section{ЗАО «НПФ «Люминофор»}

\section{Уникальное российское предприятие с полувековой историей}

ЗАО «НПФ «Люминофор» является правопреемником Всесоюзного научно-исследовательского института люминофоров и особо чистых веществ (ВНИИЛ), организованного в 1964 году в системе Государственного комитета химической промышленности при Госплане СССР.

Сегодня ЗАО «НПФ «Люминофор» - современная динамично развиваючаяся компания, которая продолжает заниматься научньмии исследованиями, технологическими разработками для российских и зарубежных предприятий, серийно выпускающая более 250 наименований продукции, значительная часть которой уникальна и не имеет аналогов в мире.

\section{МЫ ГОТОВЫ ПРЕДЛОЖИТЬ:}

- Неорганические люминофоры всех известных видов люминесценции;

- Материалы для керамических конденсаторов;

- Материалы для пьезокерамики;

- Высокочувствительные термоиндикаторные материалы

(термоиндикаторы плавления марки ТиП и термонаклейки);

- Материалы для тонкослойной оптики (пленкообразующие материалы: оксиды,

двойные оксиды, халькогениды, фториды, в том числе фториды редкоземельных, щелочноземельных и переходных металлов);

- Материалы для магнито-люминесцентной дефектоскопии;

- Люминесцентные краски для защищенной печати, декораций и дизайна;

- Визуализаторы лазерного излучения УФ-и ИК-диапазонов;

- Сцинтилляторные материалы;

- Светокорректирующие добавки, применяемые при изготовлении современных светопреобразующих материалов для парников и теплиц.

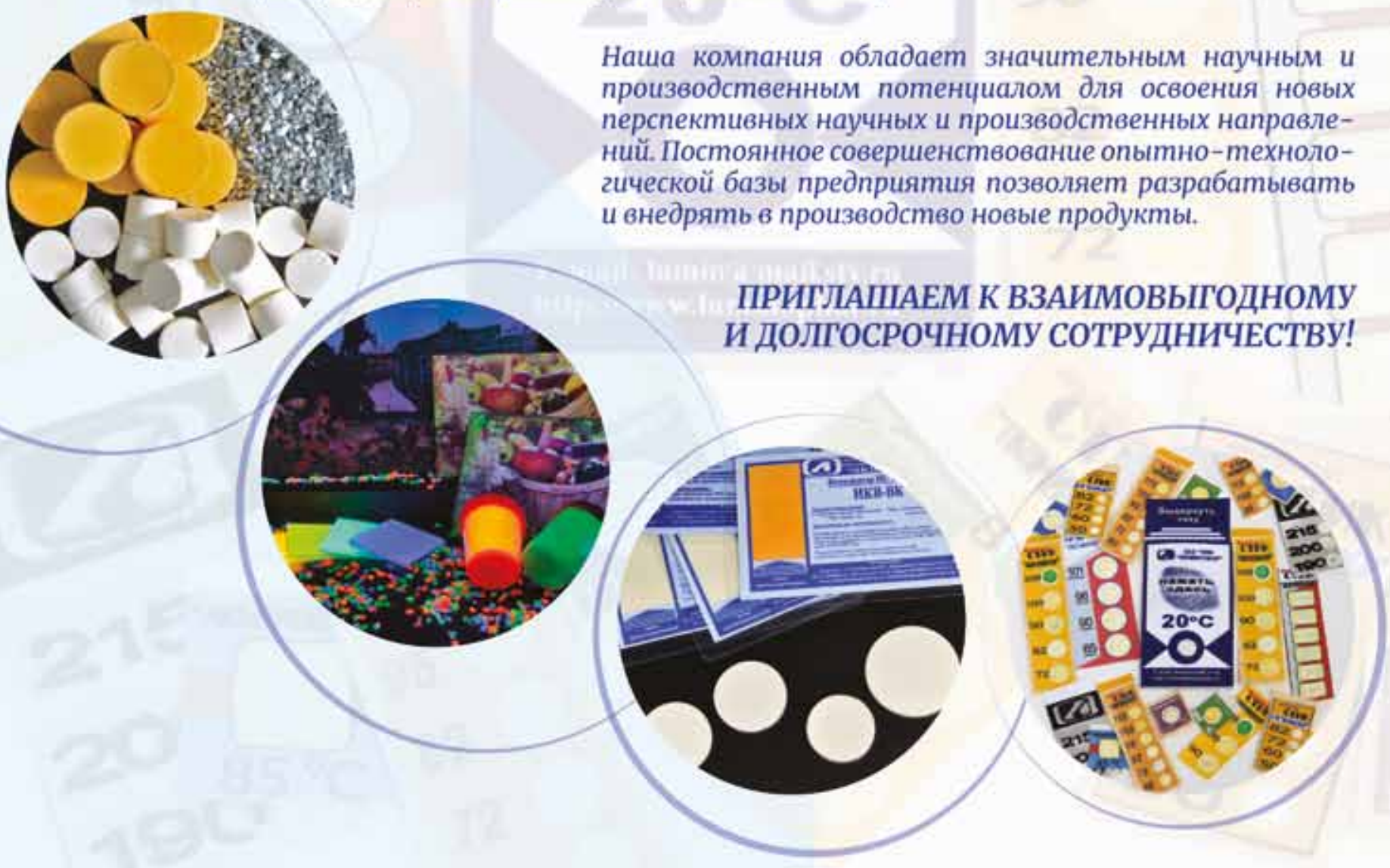

Наша компания обладает значительным научным u производственным потенциалом для освоения новых перспективных научных и производственных направлений. Постоянное совершенствование опытно-технологической базы предприятия позволяет разрабатывать и внедрять в производство новые продукты.

\section{ПРИГЛАШАЕМ К ВЗАИМОВЫГОДНОМУ И ДОЛГОСРОЧНОМУ СОТРУДНИЧЕСТВУ!}

